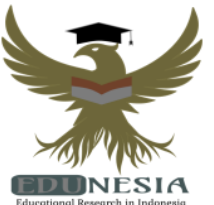

\title{
Implication of Academic Service on Student Performance
}

\author{
Ishtifa Kemal \\ Department of Indonesian Education, Universitas Muhammadiyah Sumatera Utara, Indonesia \\ Corresponding Email: isthifakemal@umsu.ac.id, Phone Number: 0896 xxxx xxxx
}

\author{
Article History: \\ Received: Okt 25, 2021 \\ Revised: Nov 20, 2021 \\ Accepted: Nov 26, 2021 \\ Online First: Nov 30, 2021
}

\section{Keywords:}

Assessment Instruments, Blended Learning.

\section{Kata Kunci:}

Instrumen Penilaian,

Pembelajaran Campuran.

\section{How to cite:}

Kemal, I. (2022). Implication od Academic Service on Studen Performance. Edunesia: Jurnal Ilmiah Pendidikan, 3 (1): 21-35.

This is an open access article under the $C C-B Y-N C-N D$ license

\begin{abstract}
This study aims to reveal: 1) student performance in the management education study program; 2) academic services carried out by the higher education management master's program at the University of North Sumatra; 3) whether there is an effect of educational services on student performance in the master's degree program in higher education management. The method used in this study is a survey method, namely by distributing questionnaires to respondents and describing respondents' answers qualitatively. Research Results: 1) Student performance of the UMSU Higher Education Management Masters Program, accustomed to being on time, taking notes from lecturers' explanations, actively preparing lecture materials, actively asking and answering questions, accustomed to making lecture summaries, filling out attendance lists, searching and reviewing source books, study groups, and participate in activities organized by the Study Program. 2) Administrative services have been carried out in an orderly and fair manner for 11 types of services, namely lecture scheduling, lecture preparation, lecture implementation, class determination, student grouping, lecture evaluation, thesis writing supervisor assignments, guidance process, implementation proposal seminars, thesis examination implementation, and student study completion process. All these services have been carried out satisfactorily and adequately. 3) There is a direct positive effect of administrative services on student performance in the higher education management study program. The results have significance for higher education. These findings can make academic service implications for student performance.
\end{abstract}

Abstrak: Penelitian ini bertujuan untuk mengungkap: 1) kinerja mahasiswa pada program studi pendidikan manajemen; 2) pelayanan akademik yang dilaksanakan oleh program studi magister manajemen pendidikan tinggi Universitas Sumatera Utara; 3) apakah ada pengaruh pelayanan pendidikan terhadap kinerja mahasiswa pada program studi magister manajemen pendidikan tinggi. Metode yang digunakan dalam penelitian ini adalah metode survei, yaitu dengan menyebarkan kuesioner kepada responden dan mendeskripsikan jawaban responden secara kualitatif. Hasil Penelitian: 1) Kinerja mahasiswa Program Studi Magister Manajemen Pendidikan Tinggi UMSU, terbiasa hadir tepat waktu, mencatat penjelasan dosen, aktif menyiapkan materi perkuliahan, aktif bertanya dan menjawab pertanyaan, terbiasa membuat ringkasan kuliah, mengisi daftar hadir, mencari dan mereview buku sumber, belajar kelompok, dan mengikuti kegiatan yang diselenggarakan oleh Program Studi. 2) Pelayanan administrasi telah dilakukan secara tertib dan adil untuk 11 jenis pelayanan yaitu penjadwalan perkuliahan, persiapan perkuliahan, pelaksanaan perkuliahan, penentuan kelas, pengelompokan mahasiswa, evaluasi perkuliahan, tugas pembimbing penulisan skripsi, proses bimbingan, seminar proposal pelaksanaan. pelaksanaan ujian tesis, dan proses penyelesaian studi mahasiswa. Semua pelayanan tersebut telah dilaksanakan dengan memuaskan dan memadai. 3) Terdapat pengaruh langsung positif pelayanan administrasi terhadap kinerja mahasiswa pada program studi manajemen pendidikan tinggi. Hasilnya memiliki arti penting bagi pendidikan tinggi. Temuan ini dapat membuat implikasi layanan akademik untuk kinerja siswa. 


\section{A. Introduction}

Universitas Muhamadiyah Sumatera Utara (UMSU) is determined to provide excellent service to its customers. This service implements academic activities and administrative activities of high quality, fast, and following customer demands or needs (Sumarni, 2018). This excellent service's estuary is customer satisfaction for users of Education services (Amin, 2019), including student satisfaction, lecturers, employees, graduate users, and users of research and community service results. To expected excellent service, improvements need to be made, especially those related to academic issues.

Early observations were made that academic services at UMSU have not seen the service process for all the needs of students, lecturers, and graduate users. Of course, excellent service is needed in the management of higher education

There are two terms of customers in the education delivery system: internal customers and external customers (Sarifudin \& Maya, 2019). Internal customers are education managers who have the primary task and function of providing services to external customers, namely students and fellow partners. efficiency and effectiveness of achieving the quality of services provided is an indicator of human resource performance (Tanjung \& Adawiyah, 2018). For students, the resulting performance is manifested in academic competence (Adiputra \& Mujiyati, 2017) and behaviour change (Ahmad et al., 2018) which are ready to face the needs of an increasingly dynamic work world. Changes in students' behaviour when they become graduates can be implemented in the form of work activities in their respective institutions. These behaviours get a positive or negative response from the graduates where the graduates work. Whereas for managers, work behaviour reflects their performance (Suwarto, 2020), which provides services that are per the students' standards and expected.

To realize and maintain students' performance as an external customer component, an organization/institution must do four things: identify the characteristics of its customers, understand their expectations of quality, understand service quality planning, and understand the evaluation system for customer satisfaction (Indrajaya, 2018). Schnaars (1991) argues that customer satisfaction is a long-term strategy that requires commitment, both from funds and human resources (Akbar, 2020).

Academic service in this study identifies with the service concept described by Brady and Cronin (2001) as a model consisting of three components: interaction, physical environment, and results (Bagasworo, 2019). Furthermore, Rust \& Oliver (1994) explain that this model's conceptualization is based on the service product model's three components, service delivery and service environment (Khader \& Madhavi, 2017). Service products are specifications of services offered to customers. The service environment is the setting and facilities needed to deliver services to customers, which will affect the beliefs, attitudes and performance of employees/employees and customers. This environment consists of the internal environment and the external environment. Meanwhile, service delivery provides services in delivering services and expectations of employees and customers' rolesemployees and customers' roles.

Furthermore, Gronroos (2000) explains that interaction dimensions include employees/service employees' attitudes, behaviour, and skills. The physical environment dimension consists of conditions (non-visual, temperature, smell, music), facility design, and social factors. The facility design includes layout and environmental conditions, practical and aesthetic design. Meanwhile, social factors include the number and behaviour of people in service settings. The yield dimension is the waiting time for service delivery. 
The measured waiting time is the customer's perception of the length of time waiting for service delivery. Tangible evidence reflects relevant physical facilities in services, and valence refers to attributes that affect customer confidence that service results are good or bad (Elvita \& Suhaeni, 2017) (Satriyono \& Kristanti, 2018).

Customers will perceive service quality based on performance evaluations at various levels and combine them to determine the overall service quality perception (Nazirah \& Utami, 2017). According to Tjiptono (2014), external customers in modern concepts buy and use company products. in comparison, internal customers are those in one organization and who use the services of other work units (Armansyah \& Jailani, 2020). Kotler (1994) explains that customer satisfaction is the level of a person's feelings after comparing their performance to his expectations (Prasilowati et al., 2021). Several methods in measuring customer satisfaction, described by Kotler and Keller (2009), are customer satisfaction surveys (Mulyapradana et al., 2020). Customer satisfaction survey methods can be done, among others, by asking respondents about how much they expect a specific attribute and how much they feel.

Customer satisfaction is one of the main goals of managing an institution / non-profit organization such as an educational institution (Nasution, 2019). Therefore, the implementation of management functions in educational institutions needs to improve the quality of educational services expected by its customers. In the field of education, quality services cannot be static. Customer perceptions will continue to evolve along with the continuity of the interrelationships between human resources as service providers and customers as stakeholders who need services, including users. Thus, interaction is a process of "moments of truth" in quality-oriented education management, and the perception of quality or quality will develop dynamically (Habibi, 2020). For this purpose, educational institutions that provide services need to provide human resources that can sustainably make changes and carry out organizational learning (learning process). The ability to make continuous changes in various aspects of corporate life and organizational learning can improve Human Resources' performance in the organization (Syafii \& Ulinnuha, 2018) (Hendrawan et al., 2020).

Robbins (Robbins \& Judge, 2017) explains that performance is an employee's work behaviour that exceeds expectations, helping others in a team, volunteering for extra work, avoiding conflicts, following rules and regulations. In detail, Colquitt explains that performance is employee behaviour that contributes either positively or negatively to organizational goals (Rosyati et al., 2020). August W. Smith explained that performance results from a process carried out by humans (Meyliana et al., 2018). In this sense, performance leads to more process activities, although in this case, Smith has combined two meanings between process and work results. Thus, a version is a work achieved by a person under their authority and responsibility to achieve organizational goals.

Ivancevich (2003: 33) explains five factors in measuring a person's performance, namely personal attitudes of workers, implementation strategies, planning, organization, opportunities provided and increased skills. Kenneth N. Wexley and Scoth A. Sneel in Dale A. Timpe (1993) describe the performance as the culmination of three interrelated elements: skills, level of effort, and external circumstances (Djaenudin, 2018). Robbins revealed several jobs related to group performance to foster and improve performance, starting with knowledge of an organization's most extensive and strategic factors. Selection structures and reward systems and giving rewards to members of the organizational group who achieve achievements. 
Robbins suggests three popular tools in performance evaluation are: (1) individual task results, (2) behaviour (action), and (3) traits. Payaman J. Simanjuntak (2005) explained that performance improvement is part of performance management activities (Najib, 2019). I clarified that all activities are a continuous process in performance management in a cycle consisting of planning, coaching, and evaluation. Meanwhile, Payaman J. Simanjuntak (Simanjuntak, 2011) explains that the leadership's performance coaching is intended to improve each individual, group, or work unit's performance.

In carrying out performance improvements, there must be clear performance standards. Standards that measure the achievement of the expected level of performance and are stated in a quantitative statement. One performance standard-setting can refer to existing laws and regulations, expert opinion, management decision, or similar work experience. The requirements for performance standards consist of: can be achieved according to existing conditions, easy to understand and apply, measurable and can be spread over a long period, can be accounted for, under applicable regulations, and can be used as a comparison by the parties concerned. By conducting observations, surveys, and interviews, collecting performance data aims to obtain progress information from each performance indicator, including effectiveness, efficiency, timeliness, accountability, and program implementation's integrity formulated in strategic planning.

According to Vincent (2006: 212), performance measurement in a performance management system is a tool for assessing the success and failure of implementing organizational strategies in achieving its goals and objectives. Performance measurement needs to be articulated with the organization's vision/mission, corporate goals and objectives. Performance measurement itself is based on determining performance indicators and the results to be achieved. The main factors in performance measurement consist of planning the objectives, targets and strategies for their achievement, developing a measurable measurement system, using information and formally reporting results. Performance measurement can be done by comparing planned performance with performance results, comparing existing performance with previous performance results, comparing one agency's interpretation with another, and comparing performance based on existing standards. There are several steps in developing a performance measurement method: preparing an annual work plan, establishing a vision, mission, objectives, objectives and delivery strategy, and determining activity performance indicators based on input, process, output, process, outcome, benefit impact indicators.

Dale (2002: 13) states that effective performance measures consist of quantitative measures, balanced, quickly understood and monitored and published. Performance evaluation focuses on evaluating inputs, processes, outputs, results, and impacts. The advantages of assessing performance are improvements in planning and strategy, policy and decision making, improvements in inputs, processes and outputs, and improvements in procedures/systems. Evaluation of the performance of activities and targets is carried out using an input, process and output analysis approach. Program evaluation is carried out to find answers to outcomes with program logic analysis, evaluation design, evaluation design preparation, and data collection and analysis strategies. Meanwhile, policy evaluation is carried out until the impact occurs; the stages of problem identification, problem formulation, alternative formulation, criteria preparation, alternative selection, policy recommendation preparation, and policy implementation plan.

In previous research, Davies \& Thomas (2002) said that professional and identity is very important for academic service. Meanwhile, Felder, e.al (2013) said that the types of 
differences in various measures of academic performance and attitudes as progress in academic services.

The key to success in performance measurement requires leaders who have a Sense of Urgency, namely leaders who are committed, desire high-performance organizations, align organizational strategy with organizational goals and activities, improve corporate quality, and align with administrative, strategic direction. Conceptually in developing performance, the organization must be oriented towards quality management and a framework that must apply

\section{B. Method}

They carried out this research at the Higher Education Management Masters Study Program, Universitas Muhammadiyah Sumatera Utara, from April to September 2021. In this study, the research subjects were students of the Higher Education Management Masters Study Program who were still active and sat at least in the 2021 academic year. the research subject has received adequate educational services from the Master of Higher Education Management Study Program, Universitas Muhammadiyah Sumatera Utara, and can state objective conditions regarding research variables.

The research method used is the survey method, which describes the opinion of the respondents obtained from the distribution of the instrument. In this study, the unit of analysis is an active student of the Higher Education Management Masters Study Program. The sample frame is estimated at 150 people. While the number of samples taken based on purposive sampling technique and used as many as 75 students.

Data collection was carried out by distributing questionnaires asking students' opinions on academic services carried out by the Master of Higher Education Management Study Program, Universitas Muhammadiyah Sumatera Utara. Respondents were directed to provide a checklist on the alternative answer choices (options) following the statement issued.

Data analysis was carried out qualitatively and the meaning of each research finding was carried out qualitatively. The stages of interpretation of research results are carried out through the following steps: (1) Data collection, through filling out the questionnaire/questionnaire that has been provided and analyzing documents to track alumni whereabouts, (2) Data reduction, by summarizing and analyzing the data obtained from the results of the distribution. questionnaire/questionnaire (3) Data Verification, namely interpreting the data and determining the meaning of the analysis results obtained.

\section{Result and Discussion}

\section{Result}

The samples in this study were grouped based on gender and study period. The total sample size is 75 students with the following distribution: on gender, it is known that the male sample is 25 or $33 \%$ and 50 or $67 \%$ female. Based on the study period, it is known that the model with a study period of fewer than seven semesters is five people or $6.7 \%$, and a study period of 7 semesters and above is 70 people or $93 \%$. Information is obtained from the data collection results to explain academic services and their implications for student performance. 


\section{Academic Services For The Master Of Management Study Program In Higher Education, Universitas Muhammadiyah Sumatera Utara}

Eleven academic services that are the object of study in this research, namely 1. Class scheduling services, 2. Class preparation services, 3. Lecture implementation services, 4. Class management services, 5 . Student grouping services, 6 . Class evaluation services, 7 Services final assignment writing supervisor, 8. final assignment writing guidance service, 9. proposal seminar service, 10. final assignment examination service and 11. student study completion service.

From the data collection, information was obtained that the eleven academic services mentioned above were realized by the UMSU Higher Education Management Study Program, which was obtained from the opinions of UMSU students. Lecture scheduling services carried out by the Master of Education Management Study Program are as follows: 75 or $100 \%$ of respondents stated that the scheduling was arranged by taking into account the suitability between classes, 71 or $95 \%$ of respondents stated that the lecture schedule was determined by taking into account the suitability of the lecturers' abilities with the courses being studied. he/she has, 75 or $100 \%$ of the respondents stated that they arranged the lecture schedule by paying attention to the condition of the lecture hall, and 65 or $87 \%$ of the respondents stated that they had carried out the lecture schedule consistently.

Lecture preparation services carried out by the Master of Higher Education Management Study Program are as follows: 74 or $99 \%$ of respondents stated that lecture preparation was carried out by making a lecture contract or syllabus by the lecturer. 70 or $93 \%$ of respondents stated that lecture preparation was carried out by completing textbooks that were easily obtained by students, and 62 or $83 \%$ of respondents stated that lecture preparation was carried out by completing the learning facilities needed in lectures. The service implementation of lectures carried out by the Master of Higher Education Management Study Program is as follows: 73 or $97 \%$ of respondents stated that the implementation of lectures followed a predetermined lecture schedule, 62 or $83 \%$ of respondents stated that lecture performance was equipped with adequate facilities. facilities and infrastructure, 67 or $89 \%$ of respondents said the class was fun, 68 or $91 \%$ of respondents said that lecture performance gave students the freedom to be creative, and 73 or $97 \%$ of respondents stated that class performance was sufficient for the meeting.

Classroom management services carried out by the Master of Higher Education Management Study Program are as follows: 74 or $99 \%$ of respondents stated that the arrangement of lecture rooms was carried out permanently for one semester, 65 or $87 \%$ of respondents stated that the arrangement of lecture rooms took into account the level of health. of the lecturers, 69 or $92 \%$ of respondents stated that the performance of the lecture hall took into account the age of the lecturer, and 75 or $100 \%$ of the respondents stated that the arrangement of the lecture hall did not consider the age and health of students. Student grouping services carried out by the Master of Higher Education Management Study Program are as follows: 65 or $87 \%$ of respondents stated that they had adjusted student grouping to student needs, 67 or $89 \%$ of respondents stated that they completely left the student group to the student concerned, 70 or $93 \%$ respondents stated that student grouping was not regulated by course lecturers, and 61 or $81 \%$ of respondents stated that student grouping took into account the readiness of the classrooms used. 
Lecture evaluation services carried out by the Master of Higher Education Management Study Program are as follows: 58 or $77 \%$ of respondents stated that the evaluation of courses was carried out objectively according to the ability of students, 59 or $79 \%$ of respondents stated that the evaluation of lectures was carried out by considering various aspects of student knowledge , 64 or $85 \%$ of respondents stated that the evaluation of lectures took into account student attendance, and 68 or $91 \%$ of respondents stated that the evaluation of lectures was carried out consistently with what was in the course contract. The service for determining the final assignment writing supervisor carried out by the Master of Higher Education Management Study Program is as follows: 75 or 100\% of respondents stated that the Head of the Study Program appointed a dissertation writing supervisor. 62 or $83 \%$ of respondents stated that the appointment of a thesis supervisor was based on the substance of the student's thesis study.

The final assignment writing guidance services carried out by the Master of Higher Education Management Study Program are as follows: 56 or 75\% of respondents stated that in the process of writing final project guidance, supervisors were easy to find, 59 or $79 \%$ of respondents said that in the process of writing final assignment guidance, supervisors corrected student writing, 57 or $76 \%$ of respondents stated that the guidance process was carried out on a scheduled basis, 70 or $93 \%$ of respondents stated that the guidance process was not carried out in a specific guidance room, 65 or $87 \%$ of respondents stated that in the mentoring process, the supervisor's explanation was easy to understand by students. Services for the implementation of the final project proposal seminar carried out by the Master of Higher Education Management Study Program are as follows: 63 or $84 \%$ of respondents stated that the final project proposal seminar was carried out solemnly, 65 or $87 \%$ of respondents stated that the workshop was attended by all examiners, 73 or $97 \%$ of respondents stated that the workshop was carried out in a certain courtroom, 73 or $97 \%$ of respondents stated that the performance of the seminar was to improve student final project proposals, and 71 or $95 \%$ of respondents stated that in the seminar version of the final project proposal, the length of time for processing was in accordance with the specified .

The thesis examination implementation services carried out by the Master of Higher Education Management Study Program are as follows: 73 or 97\% of respondents stated that the thesis examination was carried out solemnly, 71 or $95 \%$ of respondents noted that all examiners appointed to attend the thesis examination, 75 or $100 \%$ of respondents stated that the thesis examination was conducted in a certain courtroom, 73 or $97 \%$ of respondents stated that the length of time the research followed the provisions, and 72 or $96 \%$ of the respondents stated that the questions posed by the examiner were relevant to the substance of the thesis research. The study completion services provided by the Master of Higher Education Management Study Program are as follows: 72 or $96 \%$ of respondents stated that the completion of the study was not complicated, 69 or $92 \%$ of respondents stated that the completion of the study could be completed in a short time. time, 75 or $100 \%$ of respondents stated that the study completion process was free of charge, and 73 or $97 \%$ of respondents stated that the study completion process did not require long queues. 


\section{Student Achievement of the Master of Management Study Program at the Universitas Muhammadiyah Sumatera Utara}

There are 22 aspects of student performance that are the object of research, namely: 1. Accuracy of attendance, 2. Accuracy of assignments, 3. Activities to record lecturer explanations, 4. Preparation of lecture materials, 5. Activities to answer lecturers' questions, 6. Activities to ask lecturers, 7 Studying the nature of the lecturer's duties, 8 . Making lecture notes, 9. Filling out lecture attendance lists, 10. Finding lecture resource books, 11. Studying lecture resource books, 12. Involvement in activities organized by study programs, 13. Group study activities, 14. Discussions in dealing with lecture problems, 15. Regret for not attending lectures, 16. Student activities when lecturers are unable to attend, 17. Student obedience to class rules, 18. Confirmation of absence from lectures, 19. Assessment of lecturers' corrections, 20. Activities to help friends who have difficulty mastering lecture material, 21 . Activities to provide additional explanations in discussions, d. 22. Activities to listen to explanations of do pennies carefully.

Data collection. Information obtained that the performance of the UMSU Higher Education Management Masters Study Program students is as follows: (1) Accuracy according to respondents 70 or $93 \%$ stated that they were always present on time, 3 or $5 \%$ of respondents stated that they were often present on time, 2 or $2 \%$ rarely appeared on time. time. None of the respondents said sometimes and never came on time. (2) Accuracy of work according to respondents that 69 or $92 \%$ of respondents stated that they always did their assignments on time, 4 or $5 \%$ of respondents said they often did their assignments on time, 2 or $3 \%$ of respondents said they rarely did on time. None of the respondents said that they sometimes or never do their assignments on time.

The activity of recording lecturer explanations was found 66 or $88 \%$ of respondents stated that they always noted the lecturer's reasons, 6 or $8 \%$ of respondents stated that they often noted lecturer's explanations, 3 or $4 \%$ of respondents stated that they rarely recorded lecturer's explanations. None of the respondents sometimes said or never recorded the lecturer's explanation. In the preparation of lecture materials, the results were 52 or $69 \%$ of respondents stated that they always prepared lecture materials, 20 or $27 \%$ of respondents said they often prepared lecture materials, 3 or $4 \%$ of respondents said they rarely prepared lecture materials. There are no respondents who sometimes say and never prepare lecture materials. The activity of answering lecturer's questions was obtained by 41 or $55 \%$ of respondents stating that they always answered lecturer's questions, 33 or $44 \%$ said they often answered lecturer's questions, 1 or $1 \%$ of respondents stated that they rarely answered lecturer's questions.

Questioning activity was found. There were respondents who said they always asked the lecturers, 49 or $65 \%$ said they often asked the lecturers, 2 in the study program or $3 \%$ of the respondents said they rarely asked the lecturers. In the study of the nature of assignments given by lecturers, 17 or $23 \%$ of respondents said they often studied the nature of projects given by lecturers, 50 or $67 \%$ of respondents said they rarely studied the essence of assignments given by lecturers. lecturers, 8 or $11 \%$ of respondents stated that sometimes they came on time. The making of lecture summaries was obtained by 20 or $27 \%$ of respondents who stated that they always made lecture summaries, 54 or $72 \%$ of respondents stated that they often made lecture summaries, 1 or $1 \%$ of respondents stated that they rarely made lecture summaries. None of the respondents said that they sometimes and never made lecture summaries. 
For filling out the attendance list, 75 or $100 \%$ of respondents stated that they always filled out the attendance list; none of the respondents stated that they often, rarely, sometimes, and never attended the attendance list. In searching for lecture materials, 27 or $36 \%$ of respondents stated that they always look for books as sources of lecture materials, 43 or $57 \%$ of respondents stated that they often look for books as sources of lecture materials, 5 or $7 \%$ of respondents stated that they rarely look for textbooks for sources of lecture materials. None of the respondents said that they sometimes and never looked for textbooks for lecture materials. As a result, 31 or $41 \%$ of respondents stated that they always reviewed source books for lecture material, 37 or $49 \%$ of respondents stated that they often studied book sources for lecture material, 7 or $9 \%$ of respondents stated that they rarely studied books. source of lecture materials.

Involvement in activities organized by the study program. 29 or $39 \%$ of respondents stated that they always participated in activities organized by study programs, 40 or $53 \%$ of respondents stated that they often participated in activities organized by study programs, 6 or $8 \%$ of respondents stated that they rarely participated in activities organized by study programs. There were no respondents who stated that they sometimes and never participated in study program activities. Group learning activities: 12 or $16 \%$ of respondents stated that they always prioritized group learning, 27 or $36 \%$ of respondents stated that they often prioritized group learning, 30 or $40 \%$ of respondents stated that they rarely prioritized group learning, 6 or $8 \%$ of respondents stated that sometimes they prioritized group learning, None of the respondents said that they never prioritized group learning. Discussing solving problems in lectures: 67 or $89 \%$ of respondents said they always discussed solving problems in lectures, 6 or $8 \%$ of respondents said they often discussed solving problems in lectures, 2 or $3 \%$ of respondents said they rarely discussed solving problems in lectures.

Regret not attending lectures: 25 or $33 \%$ of respondents stated that they always regret not attending lectures, 31 or $41 \%$ of respondents said they often regret not attending lectures, 10 or $13 \%$ of respondents stated that they rarely regret not attending lectures, 9 or $12 \%$ of respondents stated that they sometimes regret not attending college. Student activities when the lecturer is unable to attend class. 28 or $37 \%$ of respondents stated that they always study independently when the lecturer was unable to attend, 37 or $49 \%$ of respondents stated that they often saw themselves when the lecturer was unable to attend, 7 or $9 \%$ of respondents stated that they rarely studied independently when the lecturer was unable to attend.

Compliance with the provisions that apply in lectures: 75 or $100 \%$ of respondents stated that they always obey the clauses that apply in class; none of the respondents said often, rarely, sometimes, and never followed the relevant provisions in lectures. Confirmation of absenteeism from lectures: 33 or $44 \%$ of respondents stated that they always confirmed absenteeism from college, 36 or $48 \%$ of respondents said that they often confirmed absenteeism from college, 6 or $8 \%$ of respondents stated that they rarely confirmed absence from college, none of respondents stated that they were occasionally and never confirmed absences. from college.

Lecturer correction assessment: 31 or $41 \%$ of respondents stated that they always checked lecturer's corrections, 42 or $56 \%$ of respondents stated that they often assessed lecturer revisions, 1 or $1 \%$ of respondents stated that they rarely estimated lecturer corrections, 1 or $1 \%$ of respondents stated that they sometimes did In the study of lecturer corrections, none of the respondents stated that they had never reviewed lecturer 
revisions. Efforts to help friends who have difficulty understanding the subject matter: 28 or $37 \%$ of respondents said they always help friends who have difficulty understanding the subject matter, 40 or $53 \%$ of respondents said they often help friends who have difficulty understanding the subject matter, 5 or $7 \%$ of respondents said they rarely help friends who have difficulty understand the subject matter, 2 or $3 \%$ of respondents stated that sometimes they help friends who have difficulty understanding the subject matter, no respondents say they have never helped friends who have difficulty understanding the subject matter. Activities to provide additional explanations during discussions: 7 or $9 \%$ of respondents stated that they always gave other answers when discussing, 50 or $67 \%$ of respondents stated that they often gave additional explanations during discussions, 11 or $15 \%$ of respondents said they rarely offered different resolutions when speaking, 6 or $8 \%$ of respondents stated that they sometimes provide additional explanation.

\section{Discussion}

Based on the results of the data description, information was obtained that academic services and student performance of the Master of Management Study Program in Higher Education, UMSU can be explained as follows:

\section{Academic Service}

Based on the information described above, it can be explained that the 11 academic services in the Master of Higher Education Management Study Program, UMSU are as follows: Lecture schedules are generally arranged according to the nature of the class, taking into account the suitability of the lecturers, with the subjects they teach, with considering class conditions, and carried out consistently according to schedule. Only a small part of the lecture schedule that does not follow the things above.

The arrangement of lectures by the Master of Higher Education Management Study Program has been carried out correctly. Lectures are generally carried out through lecturers who provide syllabus / lecture contracts, equipped with easily available learning resources and adequate learning tools. Only a small part of the preparation for lectures is not done properly. The implementation of lectures for the UMSU Master of Education Management Study Program in general has followed a predetermined schedule, equipped with adequate lecture facilities, carried out in a pleasant atmosphere, and a sufficient number of meetings. In the implementation of lectures, lecturers free students to be creative. Only a small part of the class's performance is not what it should be.

The arrangement of the lecture halls carried out by the Master of Education Management Study Program has generally been well served. The lecture hall does not change for one semester and is arranged taking into account the health condition and age of the lecturer. The grouping of students carried out by the Master of Higher Education Management Study Program has been carried out well, namely the grouping of students according to their wishes, according to their needs, not regulated by the lecturer who is the subject and carried out with class readiness. The evaluation of lectures in the Master of Higher Education Management Study Program has been carried out well; that is, course evaluations are generally carried out objectively, taking into account various aspects of student abilities, and are consistent with those in the course contract. However, there are still lecture evaluations that are not objective, do not consider various aspects of student 
abilities, do not consider student attendance in the assessment process, and are carried out in changes.

The determination of the thesis writing supervisor carried out by the Master of Higher Education Management Study Program is that the conclusion of the thesis writing supervisor is carried out on the wishes of the student and is determined by the head of the study program with the substance of the study. it is in accordance with the supervisor's ability. A small number of supervisors are appointed only by the Head of the Study Program and not based on the substance of the student's thesis study.

The implementation of thesis writing guidance carried out by the Master of Higher Education Management Study Program, namely thesis guidance is carried out using a supervisor who is easily found. Mentors correct students' writing, mentoring is done unscheduled, and mentoring is not carried out in certain rooms. A small number of thesis writing supervisors are hard to find

Student writing is not corrected, mentoring is carried out on a scheduled basis, guidance is carried out in a certain room, and lecturer corrections are difficult for students to understand. The thesis proposal seminar is conducted by the Higher Education Management Masters Study Program. The thesis proposal seminar is generally carried out in a solemn manner, attended by all appointed examiners, carried out in a certain exam room; the problem is in perfecting student thesis proposals, and the implementation time follows what has been determined. Only a small part of the implementation of the thesis proposal seminar which was carried out in a solemn manner; examiner is not present at all,

The thesis examination carried out by the Master of Higher Education Management Study Program is that the thesis examination is generally carried out in a solemn manner, attended by all appointed examiners, carried out in a particular thesis examination room. The exam time follows what has been determined and the questions follow the substance of the thesis study. Only a small part of the thesis examination was carried out solemnly, not attended by the examiners. The study completion process carried out by the Higher Education Management Masters Study Program is mostly a simple study completion process, completed in a short time, and not waiting too long in queues. Some of the completion of the study process is convoluted, not completed in a short time, and waiting too long in line.

\section{Student Achievement of the UMSU Education Management Masters Study Program}

Based on the information described above, the performance of the students of the UMSU Higher Education Management Masters Study Program is as follows: The attendance of students in lectures is generally on time, only a small proportion are rarely on time. The accuracy of students in doing coursework is that most students do their assignments on time; a small number of students who do their assignments are not on time. Almost all students take notes from the lecturers' explanations, a few students rarely take notes from the lecturers' explanations. Practically all students prepare lecture material that will be discussed in class lectures. Only a small number of students did not prepare lecture materials to be delivered in the lecture hall. Almost all students answered the lecturer's questions during the lecture.

Only a small number of students did not answer the lecturer's questions during the lecture. Almost all students ask lecturers about lecture material that they have not understood. Only a small number of students rarely ask lecturers about lecture material 
that they do not understand. Almost all students rarely study the nature of the assignments given by the lecturer. Only a small number of students often learn the essence of the assignments given by the lecturer. Almost all students make summaries of the Lectures discussed in Lectures in class. Only a small number of students rarely make summaries of the lectures discussed in the lecture hall. All students fill out the attendance list for the class. There are no students who do not fill in the attendance list for courses in the lecture hall. Most students look for textbooks that are discussed in class. Only a small number of students rarely look for source books for lecture materials discussed in the lecture hall.

Most of the students reviewed the source books for lecture materials discussed in lectures. Only a small number of students rarely check the source books for lecture materials discussed in the lecture hall. Almost all students take part in activities organized by the study program. Only a small number of students rarely participate in activities organized by the Study Program. In general, students prioritize group learning to understand the lecture material discussed in class lectures. Less than half of students rarely prioritize group study to understand the subject matter discussed in class talks. Only a small number of students sometimes prioritize group learning to understand the subject matter discussed in class. Almost all students discuss problem solving in class. Only a small number of students rarely discuss problem solving in class. More than half of the students felt sorry for not being present in class. Nearly half of the students did not regret not attending class. Almost all students study independently when the lecturer is unable to attend class. Only a small number of students do not study independently when the lecturer is unable to attend class.

All students comply with the provisions that apply in the lecture. There are no students who do not meet the applicable requirements in the course. Almost all students confirmed their absence from class. Only a small percentage of students did not verify their absence from the study. Practically all students evaluate the lecturer's correction of his work. Only a small number of students did not evaluate the revision of their lecturer's work. Almost all students help friends who have difficulty understanding the lecture material delivered by the lecturer in class. Only a small number of students did not help their friends who had difficulty understanding the lecture material presented by the lecturer in class. More than half of the students provided additional explanations when discussed in class. Almost half of the students offered no other reason when speaking in class. Practically all students listened carefully to the lecturer's explanation in class. Only a small number of students did not listen carefully to the lecturer's answers in class.

\section{Conclusion}

Based on the information described above, it can be concluded that the 11 academic services carried out by the UMSU Higher Education Management Masters Study Program are as follows: Lecture scheduling is arranged according to the nature of the class, taking into account the suitability of the lecturers' abilities with the subjects being taught, with class conditions, and with consistency. Student performance is directly related to the effectiveness of academic services for the UMSU Higher Education Management Masters Study Program. Thus, the logical implication is that the point of student achievement may be caused by the effectiveness of academic services carried out by the UMSU Education Management Masters Study Program. Of the 11 administrative services studied, all of them have been implemented well, although some have not been maximized. Likewise, student 
performance as measured by 21 indicators shows that all of these indicators have been implemented well by students and are useful. So the effectiveness of student performance is caused by the point of academic service provided by the study program to students.

Based on the conclusions above, several things can be suggested as follows. (1) In preparing lectures, lecturers should prepare textbooks or reference books used in the classroom as well as various supporting facilities, (2) In establishing lecture halls, the Study Program should pay attention to the health condition and age of lecturers and students, (3) In conducting evaluation of lectures, lecturers should evaluate objectively, consider various aspects of students' abilities in giving final grades to students, consider student attendance in class in determining the final stage, and be consistent with what is stated in the lecture contract, (4) At the time of the proposal seminar exam the thesis is carried out, the Study Program seeks an exam room that meets the requirements for the level of comfort, (5) In determining the thesis writing supervisor, the study program must look at the supervisor who masters the substance of the student study material in the thesis that he will write, (6) During the guidance process, the supervisor does not difficult to contact by maha students who will provide guidance, (7) thesis writing guidance by supervisors should be scheduled in an orderly manner, (8) Study Programs and supervisors should provide a special room for guidance.

\section{References}

Adiputra, S., \& Mujiyati. (2017). Motivasi dan Prestasi Belajar Siswa di Indonesia: Kajian Meta-Analisis. Konselor, 6(4). https:/ / doi.org/10.24036/02017648171-0-00

Ahmad, Hajar, S., \& Almu, F. F. (2018). Peningkatan Keterampilan Menyimak Cerita Anak Melalui Media Animasi Audio Visual Siswa Kelas VI SD. Jurnal Ilmiah Profesi Pendidikan, 3(1). https://doi.org/10.29303/jipp.v3i1.44

Akbar, M. (2020). Sinergitas Public Relations PT.PLN (Persero) Wilayah Sulawesi Selatan Tenggara Dengan Media Massa Dalam Upaya Pemenuhan Kepuasan Pelanggan. Jurnalisa: Jurnal Jurusan Jurnalistik, 6(1). https://doi.org/10.24252/jurnalisa.v6i1.13782

Amin, S. (2019). Strategi Peningkatan Kualitas Pelayanan Akademik pada Perguruan Tinggi. Journal of Chemical Information and Modeling, 53(9). https://journal.walisongo.ac.id >

Armansyah, \& Jailani, M. N. (2020). Pengaruh Kualitas Pelayanan Terhadap Kepuasan Pelanggan Pada PT. Ramayana Lestari Sentosa Ciputat. Jurnal Disrupsi Bisnis, 3(2). http://dx.doi.org/10.32493/drb.v3i2.6294

Bagasworo, W. (2019). Pengaruh Kualitas Jasa Pendidikan Terhadap Kepuasan Mahasiswa 2015-2018 di STIE Indonesia Banking School. Jurnal Ekonomi, Manajemen Dan Perbankan (Journal of Economics, Management and Banking), 5(3), 170-174. https://doi.org/10.35384/jemp.v5i3.156

Davies, Annette., Thomas, Robyn. (2002). Managerialism and Accountability in Higher Education: The Gendered Nature of Restructuring and The Costs to Academic Service. Critical Perspective on Accounting, 13 (2), pp. 179-193. https://doi.org/10.1006/cpac.2001.0497Get rights and content

Djaenudin, A. (2018). Budaya Organisasi Dalam Meningkatkan Prestasi Kerja Pegawai Di Balai Diklat Aparatur Sukamandi Kementerian Kelautan Dan Perikanan. Eqien: Jurnal Ekonomi Dan Bisnis, 9(1). https:// doi.org/10.34308/eqien.v5i2.61 
Elvita, D., \& Suhaeni, T. (2017). Pengaruh Kinerja Pelayanan Terhadap Loyalitas Pelanggan. Jurnal Riset Bisnis Dan Investasi, 3(1). https:/ / doi.org/10.35313/jrbi.v3i1.544

Felder, R.M., Felder, G.N., Dietz, E.J., (2013). The Effects of Personality Type on Engineering Student Performance and Attitudes. Journal of Engineering Education, 91 (1), pp. 3-7. https:// doi.org/10.1002/j.2168-9830.2002.tb00667.x

Habibi, M. R. (2020). Manajemen Pengendalian Mutu Di Sekolah Dasar Negeri Surabaya Barabali, Lombok Tengah. NUSRA: Jurnal Penelitian Dan Ilmu Pendidikan, 1(2). https://ejournal.nusantaraglobal.ac.id/index.php/nusra/article/view/17

Hendrawan, A., Sucahyowati, H., Rayendra, A., \& Indriyani, I. (2020). Berbagi Pengetahuan Dan Pembelajaran Organisasi Dalam Upaya Peningkatan Kinerja Karyawan. Jurnal Ilmu Komunikasi Dan Bisnis, http://www.journal.starki.id/index.php/JIK/article/viewFile/350/pdf

Indrajaya, D. (2018). Analisis Kualitas Pelayanan Terhadap Tingkat Kepuasan Konsumen Menggunakan Metode Importance Performance Analysis Dan Customer Satisfaction Index Pada UKM Gallery. Jurnal IKRA-ITH Teknologi, 2(3). https://journals.upi-yai.ac.id/index.php/ikraith-teknologi/article/view/325

Khader, A., \& Madhavi, C. (2017). Progression of Service Quality Concepts. Global Journal of Management and Business Research: A Administration and Management. https://journalofbusiness.org

Meyliana, Agustina, L., \& Setiawan, C. (2018). Analisis Penilaian Kinerja Organisasi Perangkat Daerah di Kota Bandung. Jurnal Akuntansi Maranatha, 10(2), 223-230. https://doi.org/10.28932/jam.v10i2.1087

Mulyapradana, A., Anjarini, A. D., \& Harnoto. (2020). Pengaruh Kualitas Pelayanan Terhadap Kepuasan Pelanggan di PT. Tempo Cabang Tegal. Jurnal Ekonomi $\mathcal{E}$ Ekonomi Syariah, 3(1). 10.36778/jesya.v3i1.115

Najib, M. (2019). Peranan Kinerja Dalam Meningkatkan Efektivitas Kerja Karyawan Pada PT. Bumi Alam Persada Ogan Ilir. Jurnal Media Wahana Ekonomika, 15(4), 60-74. http://dx.doi.org/10.31851/jmwe.v15i4.3058

Nasution, M. H. (2019). Manajemen Mutu Terpadu (MMT) Dalam Pendidikan Islam. AlMuaddib: Jurnal Ilmu-Ilmu Sosial Dan Keislaman, 4(2). http://dx.doi.org/10.31604/muaddib.v4i2.228-248

Nazirah, U., \& Utami, S. (2017). Pengaruh Kualitas Desain Website Terhadap Niat Pembelian Dimediasi Oleh Persepsi Kualitas Produk Pada Lazada.co.id. Jurnal Ilmiah Mahasiswa Ekonomi Manajemen, 2(3). https:/ / doi.org/10.24815/jimen.v2i3.3504

Prasilowati, S. L., Suyanto, S., Safitri, J., \& Wardani, M. K. (2021). The Impact of Service Quality on Customer Satisfaction: The Role of Price. Journal of Asian Finance, Economics and Business, 8(1). 10.13106/jafeb.2021.vol8.no1.451

Robbins, S. P., \& Judge, T. A. (2017). Organizational Behavior, 17th edition (Global Edi). Pearson Education Limited. https://www.pearson.com/uk/educators/highereducation-educators/ program/Robbins-Organizational-Behavior-Global-Edition17th-Edition/PGM1097472.html

Rosyati, T., Saprudin, \& Syukron, A. (2020). Kinerja OCB Pada Guru PAUD Ditinjau Dari Educational Leadership Dan Integritas. Jurnal Obsesi: Jurnal Pendidikan Anak Usia Dini, 5(1), 201-211. 10.31004/obsesi.v5i1.513

Sarifudin, \& Maya, R. (2019). Implementasi Manajemen Pemasaran Jasa Pendidikan Dalam Meningkatkan Kepuasan Pelanggan Di Madrasah Aliyah Terpadu (MAT) Darul 
Fallah Bogor. Islamic Management: Jurnal Manajemen Pendidikan Islam, 2(02). https:/ / doi.org/10.30868/im.v2i02.513

Satriyono, G., \& Kristanti, D. (2018). Pengaruh Kepuasan Pasien Pada Kualitas Layanan Rawat Inap Terhadap Niat Discharge Against Medical Advice (DAMA) (Studi di Rumah Sakit Umum Daerah Pare Kabupaten Kediri). Jurnal Ekonika: Jurnal Ekonomi Universitas Kadiri, 3(2). http://dx.doi.org/10.30737/ekonika.v3i2.190

Simanjuntak, P. J. (2011). Manajemen dan Evaluasi Kinerja. In FE UI. Fakultas Ekonomi Universitas Indonesia.

Sumarni, Y. (2018). Pengaruh Kualitas Pelayanan Administrasi Akademik Dan Kemahasiswaan Terhadap Kepuasan Mahasiswa Fakultas Ekonomi Dan Bisnis Islam IAIN Bengkulu. Jurnal Baabu Al-Ilmi: Ekonomi Dan Perbankan Syariah, 3(1). https://doi.org/10.29300/ba.v3i1.1474

Suwarto. (2020). Faktor-faktor yang Mempengaruhi Kinerja Pegawai. Eksis: Jurnal Ilmiah Ekonomi Dan Bisnis, 11(1), 15-24. http://dx.doi.org/10.33087/eksis.v11i1.180

Syafii, M., \& Ulinnuha, M. (2018). Pengaruh Etos Kerja Dan Budaya Organisasi Terhadap Kinerja PT. Ananda Jataka Bayu Sejahtera (AJBS) Di Kota Gresik. GEMA EKONOMI (Jurnal Fakultas Ekonomi), 7(1). 10.5281/zenodo.3477648

Tanjung, D. Y. H., \& Adawiyah, R. (2018). Perancangan Sistem Pendukung Keputusan Dengan Metode Simple Multi Attribute Rating Technique (SMART) Dalam Penilaian Kinerja Dosen ( Studi Kasus: Universitas Potensi Utama ). IT Journal, 6. http://dx.doi.org/10.22303/it.6.2.2018.149-159 